\title{
PURIFICATION OF SPENT METHYLDIETHANOLAMINE SOLUTIONS WITH ACTIVATED CARBON AU-KO
}

\author{
Isokov Yusuf Khoriddinovich ${ }^{1}$ \\ ${ }^{1}$ Basic doctoral student Institute of General and Inorganic Chemistry Academy and Sciences Of the Republic of \\ Uzbekistan, Tashkent \\ Yusupov Farkhod Makhkamovich ${ }^{2}$ \\ ${ }^{2}$ Doctor of Technical Sciences, Prof. Institute of General and Inorganic Chemistry of the Academy and Sciences of the \\ Republic of Uzbekistan, Tashkent

\section{Kurbonov Azizjon Rustamovich ${ }^{3}$} \\ ${ }^{3}$ Junior Researcher Institute of General and Inorganic Chemistry Academy and Sciences of the Republic of \\ Uzbekistan, Tashkent \\ Pulatova Zulkhumor Jaloliddin kizi ${ }^{4}$ \\ ${ }^{4}$ Teacher of the Tashkent State dental institute \\ Sultonov Sadulla Bahriddinovich ${ }^{5}$ \\ ${ }^{5}$ Junior Researcher Institute of General and Inorganic Chemistry Academy and Sciences of the Republic of Uzbekistan, \\ Tashkent \\ Yodgorov Normahmat ${ }^{6}$ \\ ${ }^{6}$ Doctor of Chemical Sciences Professor Institute of General and Inorganic Chemistry Academy and Sciences \\ of the Republic of Uzbekistan, Tashkent
}

\begin{abstract}
ANNOTATION:
The article presents the results of a study to determine the physicochemical adsorption properties and some technological parameters for the production of activated carbons based on bones. In the course of the study, the physicochemical and adsorption characteristics of the new activated carbon obtained by us from walnut seeds were determined. For the purpose of import substitution, its characteristics were compared with the well-known industrial activated carbon of the AG-3 brand.
\end{abstract}

Keywords: AG-3, activated carbon, pyrolysis, condensate, methanol.

\section{INRODUCTION}

To obtain activated carbons, the carbonization process was carried out at a temperature of $400-800^{\circ} \mathrm{C}$, which was controlled by a thermocouple located in the middle of the reactor. The temperature rise rate was $7-10^{\circ} \mathrm{C}$ per minute.

Upon reaching the required temperature of the experiment, the sample was kept in the reactor for 1-2 $\mathrm{h}$ and then cooled to room temperature. The evolved gaseous pyrolysis products were evacuated from the reactor through a gas outlet tube and sent to a cooled condenser for condensation of water and resin vapors.

Cooled carbonizates were discharged from the reactor and their absorption properties were determined using standard methods. The activation of the carbonizate was carried out in the same reactor. For activation, carbonized granules are loaded into a tubular reactor, which was purged with a stream of nitrogen gas for 15 minutes to remove oxygen from the reaction zone. The upper flange of the reactor is equipped with a branch pipe for the inlet of superheated water vapor, and the lower one has a branch pipe for withdrawing the steam-gas mixture. The superheated steam required for activation is obtained in the steam generator. The flow rate of water vapor for activation is controlled by the amount of 
water entering the steam generator by changing the rate of its flow in the capillary depending on the pressure above the water created in the dosing tank using nitrogen. The activation temperature is controlled by heating the reactor and the steam generator. The sample was heated to the final activation temperature, which was in the range $800-950{ }^{\circ} \mathrm{C}$. When the set temperature was reached, water vapor was fed into the reactor from the generator for 1-2 hours. The volume of activation gases containing hydrogen, carbon oxides, and methane after separation from unreacted water vapor is measured by a gas meter, and the chemical composition is measured by chromatography using a carbon column and thermal conductivity detector.

\section{MAIN PART}

After heat treatment, the resulting activated carbon was left to cool to room temperature without air access.

The quality of the obtained target products was controlled by measuring their bulk density, ash content, and adsorption activity with respect to benzene.

The technical characteristics of the obtained activated carbon from the nut seed shell (hereinafter AU-KO) have been determined. Some characteristics of AU-KO activated carbon are compared with the characteristics of active industrial activated carbons of the AG-3 and NH-30 brands are shown in Table 1.

Table 1

Comparative technical characteristics of activated carbon coal AG-3, NH-30 and AU-KO

\begin{tabular}{|c|c|c|c|c|}
\hline № & Indicators & Ah-3 (Russia) & $\begin{array}{l}\text { NH-30 } \\
\text { (China) }\end{array}$ & Presented Sample (AU-KO) \\
\hline 1 & $\begin{array}{l}\text { Fractional composition, } \% \\
5 \mathrm{~mm} \\
3.6 \mathrm{~mm} \\
\text { from } 2.8 \text { to } 3.6 \mathrm{~mm} \\
\text { from } 1.5 \text { to } 2.8 \mathrm{~mm} \\
\text { from } 1.0 \text { to } 1.5 \mathrm{~mm}\end{array}$ & $\begin{array}{c}0,4 \\
3 \\
86 \\
10 \\
0,6\end{array}$ & $\begin{array}{c}2 \\
10 \\
70 \\
15 \\
3\end{array}$ & $\begin{array}{c}8 \\
16 \\
64 \\
5 \\
7\end{array}$ \\
\hline 2 & Bulk density, g / dm3 & 480 & 520 & 455 \\
\hline 3 & Iodine activity, $\%$ & 88 & 98 & 86,4 \\
\hline 4 & Activity for benzene, $\%$ or $\mathrm{g} / \mathrm{dm} 3$ & $\begin{array}{c}31 \\
148\end{array}$ & $\begin{array}{c}34 \\
176\end{array}$ & $\begin{array}{c}33 \\
150,2\end{array}$ \\
\hline 5 & Total pore volume, $\mathrm{cm} 3 / \mathrm{g}$ & 0,860 & 0,692 & 0,720 \\
\hline 6 & Moisture content, $\%$ & 6 & 5 & 6 \\
\hline 7 & Solness, $\%$ & 14 & 4,2 & 7 \\
\hline 8. & Abrasion strength, $\%$ min. & 75 & 78 & 76 \\
\hline
\end{tabular}

Comparison of the results of experimental research data with the literature showed that the obtained activated carbon AU-KO in terms of adsorption activity and other physicochemical parameters is at the level of known activated carbons AG-3 and NH-30, which are one of the highest quality coals of world industrial production. Thus, the results of the conducted studies demonstrate the expediency of processing fruit seeds in the Republic to obtain carbon adsorbents for various purposes.

The composition of the purified alkanolamine solution must meet the following requirements for reuse in the amine purification of natural gas: amine degradation products - no more than $10 \%$ by weight, liquid high-molecular hydrocarbons - no more than $0.05 \%$ vol., Heat-resistant salts - $1 \%$ by weight. mechanical impurities - $500 \mathrm{mg} / 1$. All these parameters affect the foaming of the amine solution.

To carry out experiments to determine the effect of organic substances on the foaming of alkanolamines, the following reagents were selected: as a solution of alkanolamine, a $25 \%$ (wt.) DEA solution was used, and as organic substances, pentane, octane, nonane, undecane, cyclopentane, cyclohexane , fractions $120{ }^{\circ} \mathrm{C}$ and $150{ }^{\circ} \mathrm{C}$ condensate, methanol, $10 \%$ residue from the distillation of technical methanol, as well as a pure solution of DEA. At the entrance to the experiment, the height $(\mathrm{H})$ of the foam of a $25 \%$ DEA solution was determined with the addition of the above organic substances at various concentrations. The results are shown in table 2.

Results of determination Purpose of foam $25 \%$ DEA solution with various additives

Table 2. 


\begin{tabular}{|c|c|c|c|}
\hline № & Sample names & $\begin{array}{l}\text { Mass fraction of } \\
\text { additives, } \%\end{array}$ & Height of foam $\mathrm{H}, \mathrm{mm}$ \\
\hline \multirow{3}{*}{1.} & \multirow{3}{*}{ DEA + Pentan } & 0,1 & 0 \\
\hline & & 0,5 & 0 \\
\hline & & 1,0 & 3 \\
\hline \multirow{3}{*}{2.} & \multirow{3}{*}{ DEA + Octan } & 0,1 & 1 \\
\hline & & 0,5 & 4 \\
\hline & & 1,0 & 11 \\
\hline \multirow{3}{*}{3.} & \multirow{3}{*}{ DEA + Nonan } & 0,1 & 8 \\
\hline & & 0,5 & 22 \\
\hline & & 1,0 & 24 \\
\hline \multirow{3}{*}{4.} & \multirow{3}{*}{ DEA + Undekan } & 0,1 & 21 \\
\hline & & 0,5 & 32 \\
\hline & & 1,0 & 37 \\
\hline \multirow{3}{*}{5.} & \multirow{3}{*}{ DEA + cyclopentan } & 0,1 & 1 \\
\hline & & 0,5 & 3 \\
\hline & & 1,0 & 0 \\
\hline \multirow{3}{*}{6.} & \multirow{3}{*}{ DEA + Cyclohexane } & 0,1 & - \\
\hline & & 0,5 & 0 \\
\hline & & 1,0 & 5 \\
\hline \multirow{3}{*}{7.} & \multirow{3}{*}{$\mathrm{DEA}+\mathrm{FR} .120^{\circ} \mathrm{C}$ condensate } & 0,1 & 4 \\
\hline & & 0,5 & 8 \\
\hline & & 1,0 & 11 \\
\hline \multirow{3}{*}{8.} & \multirow{3}{*}{$\mathrm{DEA}+\mathrm{FR} .150^{\circ} \mathrm{C}$ condensate } & 0,1 & 8 \\
\hline & & 0,5 & 12 \\
\hline & & 1,0 & 17 \\
\hline \multirow{3}{*}{9.} & \multirow{3}{*}{ DEA + Methanol } & 0,1 & 0 \\
\hline & & 0,5 & 0 \\
\hline & & 1,0 & 0 \\
\hline \multirow{3}{*}{10.} & \multirow{3}{*}{$\begin{array}{l}\text { DEA }+10 \% \text { residue from producing } \\
\text { technical methanol }\end{array}$} & 0,1 & 0 \\
\hline & & 0,5 & 1 \\
\hline & & 1,0 & 3 \\
\hline \multirow{3}{*}{11.} & \multirow{3}{*}{ DEA + Clean DEA solution } & 0,1 & 0 \\
\hline & & 0,5 & 0 \\
\hline & & 1,0 & 0 \\
\hline
\end{tabular}

Based on the above research results in Table 1, a graph is plotted of the dependence of the foam height $(\mathrm{H})$ of a $25 \%$ DEA solution on the mass fraction of various additives (Fig. 1). 


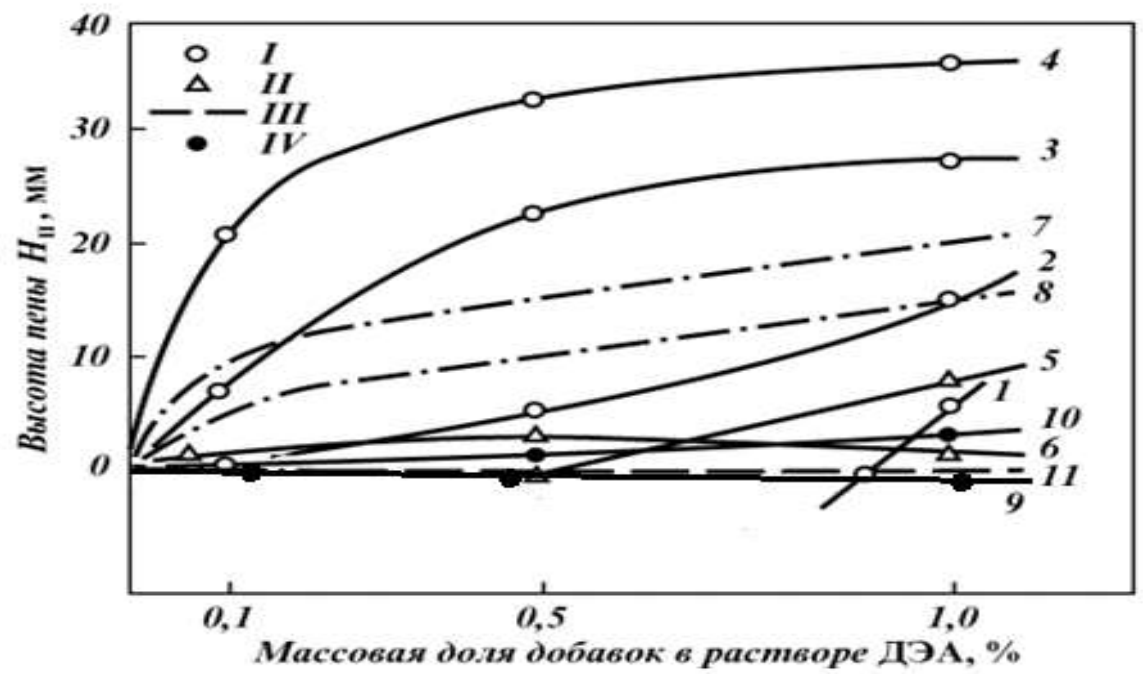

Figure: 1. Influence of various additives on the foaming ability of a $25 \%$ DEA solution:

I - paraffins; II - naphthenes; III - condensate fractions; IV - alcohols; 1 - C5H12; 2 - C8H18; 3 - C9H20; 4 - $\mathrm{C} 11 \mathrm{H} 24 ; 5$ - $\mathrm{C} 6 \mathrm{H} 12 ; 6$ - $\mathrm{C} 5 \mathrm{H} 10 ; 7$ - condensate, fraction $150^{\circ} \mathrm{C} ; 8$ - condensate, fraction $120^{\circ} \mathrm{C} ; 9$ - methanol; 10 - the remainder (10\%) from the distillation of technical methanol; 11 - pure DEA solution.

The results of the study showed that the expansion rate of the foam depends on the nature and properties of impurities in the gas coming from the field and can cause foaming of amine solutions. The greatest foaming is caused by hydrocarbons having a boiling point above $100^{\circ} \mathrm{C}$ (condensate, oil), surfactants, and some corrosion inhibitors. From the results of the experiment, it was revealed that hydrophobic substances such as paraffinic, naphthenic, aromatic hydrocarbons and condensate fractions increase the height and life of the foam, due to the formation of a strong protective film at the interface, while hydrophilic alcohols and amino alcohols reduce them or do not form foaming of the solution.

To determine the effect of inorganic substances on the foaming of alkanolamines, the following salts were chosen: $\mathrm{MgCO} 3, \mathrm{CaCO} 3, \mathrm{KCl}, \mathrm{K} 2 \mathrm{SO} 4$, and MEA solution. The results of experimental studies to determine the effect of salts $\mathrm{MgCO} 3, \mathrm{CaCO} 3, \mathrm{KCl}, \mathrm{K} 2 \mathrm{SO} 4$ on the foaming ability of the MEA solution are shown in Figure 2.

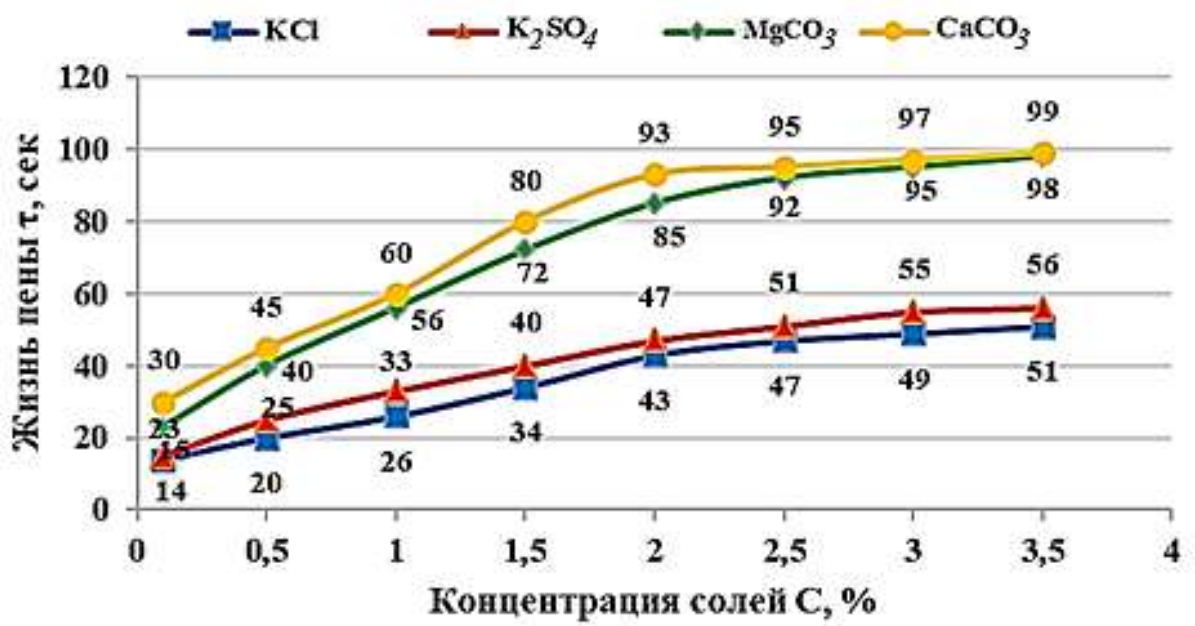

Fig. 2. The dependence of the life expectancy of the foam $\tau$ (c) on the concentration of salts with (\%) in the MEA solution

To determine the amount of mechanical impurities in the MDEA solution, three samples were taken: the initial one, purified with AG-3 activated carbon and purified with AU-KO activated carbon. The results obtained from the determination of mechanical impurities in the MDEA solution are shown in Table 3.

Table 3 
Results from determining mechanical impurities in solution MDEA

\begin{tabular}{|c|l|c|}
\hline № & \multicolumn{1}{|c|}{ MDEA solution samples } & $\begin{array}{c}\text { The amount of fur. impurities, } \\
\mathrm{mg} / 1\end{array}$ \\
\hline 1 & The original & 1068 \\
\hline 2 & Purified (AG-3) & 488 \\
\hline 3 & Purified (AU-KO) & 483 \\
\hline
\end{tabular}

So, the best results of the analyzes carried out to determine the quality of the purified MDEA solution and other physicochemical indicators (density and $\mathrm{pH}$ of the solution) are shown in Table 4.

Table 4.

Physico-chemical characteristics of a purified MDEA solution

\begin{tabular}{|c|c|c|c|c|}
\hline \multirow[t]{2}{*}{ № } & \multirow[t]{2}{*}{ Parameters } & \multicolumn{3}{|c|}{ MDEA solution samples } \\
\hline & & Source (regenerated) & $\begin{array}{l}\text { Purified (activated } \\
\text { carbon AG-3) }\end{array}$ & $\begin{array}{l}\text { Purified (activated } \\
\text { carbon AU-KO) }\end{array}$ \\
\hline 1 & $\begin{array}{l}\text { Concentration of amine, } \% \\
\text { of mass. }\end{array}$ & 40 & 39 & 55 \\
\hline 2 & $\mathrm{pH}$ & 10,80 & 10,40 & 10,40 \\
\hline 3 & Density, g / sm3 & 1,092 & 1,085 & 1,122 \\
\hline 4 & $\begin{array}{l}\text { The content of } \\
\text { thermostable salts, } \% \text { of } \\
\text { the mass. }\end{array}$ & 2,80 & 0,83 & 0,81 \\
\hline 5 & $\begin{array}{l}\text { Content of mechanical } \\
\text { impurities, } \mathrm{mg} / \mathrm{l}\end{array}$ & 1068 & 488 & 483 \\
\hline 6 & $\begin{array}{l}\text { Foaming: foam height, } \\
\text { mm life foam, sec. }\end{array}$ & $\begin{array}{l}16 \\
20\end{array}$ & $\begin{array}{c}16 \\
9\end{array}$ & $\begin{array}{c}15 \\
9\end{array}$ \\
\hline
\end{tabular}

From the above data, it follows that the working concentration of the MDEA solution increased after cleaning with AU-KO activated carbon when compared with the initial solution from 40 to 55\%, and the indicator of the AG-3 purified coal solution slightly decreased, which means that the working concentration of the MDEA solution after cleaning with coals AG-3 and AU-KO is within the limits recommended by the design organization for operation, and the density corresponds to the concentration (1.085-1.122 $\mathrm{g} / \mathrm{cm} 3)$.

The content of thermostable salts in the initial regenerated solution of MDEA is $2.80 \mathrm{wt} \%$, which exceeds the maximum permissible concentration by $1 \mathrm{wt} \%$, and in the purified solution with AG-3 and AU-KO coals their concentration is 0.83 and 0.81 respectively, which does not exceed the maximum permissible concentration.

The amount of mechanical impurities in the original regenerated amine is high - $1068 \mathrm{mg} / \mathrm{L}$, and in the purified samples with AG-3 and AU-KO coals is low - 488 and $483 \mathrm{mg} / \mathrm{L}$ when compared with the permissible concentration of $500 \mathrm{mg} / \mathrm{L}$, since their high content in amine is one of the causes of foaming and can be a foam stabilizer.

The foam height of all samples of amine solutions was at a low level (15-16 mm). The foam destruction time (foam life) of the initial amine solution was at a high point of the average level $(20 \mathrm{sec})$, while in the purified solutions with AG-3 and AU-KO coals it was at a low level $(9 \mathrm{sec})$.

\section{CONCLUSION}

In the course of the studies carried out, it was revealed that thermostable salts and mechanical impurities accumulating during the operation of gas absorption cleaning units are the main causes of foaming of working solutions of alkanolamines. Analyzing the obtained results of experiments, it was found that activated carbon from local raw materials AU-KO is not inferior to the Russian analogue of activated carbon AG-3 in terms of the cleaning ability of spent alkanolamine solutions and other technical parameters. For the purpose of import substitution of the developed activated 
carbon, AU-KO can be recommended for adsorption purification of spent alkanolamines instead of AG-3 coal.

\section{References:}

1. Шерматов Б.Э. Разработка технологии получения рекуперационных и осветляющих сорбентов из хлопкового лигнина: дис. канд. тех. наук. - Т.: Узбекский научно-исследовательский институт химической технологии и катализа, 1994. - 117 с.

2. Энциклопедия газовой промышленности - Изд. 4-е (1990) пер. с франц. Под ред. К.С. Басниева. - М.: Акционерное общество «ТВАНТ»,1994. - 884 с.

3. Агаев Г.А. Борьба с пенообразованием в процессе аминовой очистки природного газа. - М.: ВНИИЭгазпром. 1979. - 33 c.

4. Шерматов Б.Э. Разработка технологии получения рекуперационных и осветляющих сорбентов из хлопкового лигнина: дис. канд. тех. наук. - Т.: Узбекский научно-исследовательский институт химической технологии и катализа, 1994. - 117 с.

5. Энциклопедия газовой промышленности - Изд. 4-е (1990) пер. с франц. Под ред. К.С. Басниева. - М.: Акционерное общество «ТВАНТ»,1994. - 884 с.

6. Стрижов И.Н. Добыча газа. - Москва-Ижевск: Институт компьютерных исследований, 2003. - 376 с.

7. Патент РФ № 2198722 - Способ предотвращения пенообразования аминовых растворов / Лыкова Л.Ф., Пестовников О.Д., Прохоров Е.М., Тараканов Г.В., Чудиевич Д.А. Подача заявки: 08.06.2001, публикация патента: 20.02.2003. 